\title{
Perspective of Samara-Italian Relations in the Tourism
}

\section{Gleb Aleksushin}

\author{
Samara State Economic University, Samara, Russia; Email: gva3@yandex.ru
}

\section{Doi:10.5901/mjss.2015.v6n6s3p430}

\section{Abstract}

The modern tourist industry is one of the most dynamically developing sectors of world economy and contributes significantly to the formation of the gross domestic product, increase of the balance of payments. It plays an important role in the socioeconomic development of the state, contributes to improving the quality of life of the population. In addition, the tourism industry relates to sectors that have significant multiplicative effect in terms of the creation of demand for products related sectors of the economy and employment of the population. At the moment Samara region-Italian relations in tourism are lacking. There are no studies on this topic. The problem, however, is: the flow of tourists increases every year. Samara tourists increasingly travel abroad, including to Italy. Italian tourists often visit Russia, but to Samara are rarely. What steps need to be taken to change the situation?

Keywords: Europe, Italy, Samara, Samara region, tourism, tourist, tourist product

\section{Introduction}

The number of tourists in the world is constantly increasing.

Thus, the proportion of tourists visiting classic Europe, is gradually declining. European tourist product aging, $90 \%$ of its users - the Europeans (Bondarovich, Recreational, 2003).

Europe ranks first in the world in the number of foreign tourists, and Italy is one of the most popular countries to visit.

The number of tourists to Russia is growing, albeit slowly (Table 1). Increases the flow of Italian tourists to our country. However, Samara gets very small part of this flow. Samara region, despite the rich tourism resources, inadequate levels of tourism. One of the main problems in the formation of this situation was the secrecy in which Samara region lived until 1991.

These problems pose to Italy and the Samara region the same problem of the need to increase foreign tourism. And, the best way to solve these problems together - Increasing streams of tourists to each other. With the help of this approach, Italy and the Samara region will be able to increase the number of tourists on its territory. What you need to do?

For beginning, the necessary analysis of the problems in the organization of tourism from Samara region (Russia) and Italy.

\section{Method}

Methods major - comparative analysis, search of interesting resources, the search directions of development of tourism.

The comparison of climate data and data on tourism flows from Italy to Russia and from Russia to Italy will give an idea about the state of Russian-italian tourism and the possible directions of its development.

In Samara it is necessary to find interesting for Italians natural, historical and cultural resources. In Italy it is necessary to find interesting for Samara's residents natural, historical and cultural resources.

In difficult financial crisis need the use of community efforts in the development of tourism.

\section{Results}

\subsection{Comparative analysis Italy and Samara region}

The travel of Russian tourists to Italy is a stable on 9 places. Russia in the priorities of Italian tourists varies 6-7 places 
(Table 2). The ratio of Russian tourists in Italy to Italian in Russia is constantly increasing: 1,68:1 (2007), 2,29:1 (2008), 2,33:1 (2009). 3:1 (2010). 3,22:1 (2011), 4,84:1 (2012).

If Russian tourists in Italy are interested in monuments, shopping, beaches and cuisine, the Italians in the Samara region will be interested in nature, the monuments of the twentieth century, a different climatic zone, Russian cuisine and music and military-historical festivals.

The 2013-2014 year was proclaimed the cross-Year of tourism in Italy and Russia. Throughout the year, was planned several activities for the rapprochement of our countries and people. One of the key objectives was to attract tourists in the small historic town and the opening of unknown areas in both countries. The General Consul of Italy in St. Petersburg, Leonardo Bencini at the meeting of the partner countries on 1 October 2014 summed up the year of tourism Italy-Russia. He announced a new program for tourists, which visit Italy twice a year will get a visa for 3 years. They have the passport must be 3 or more Schengen visas for 2013-2014, one of which is Italian, and at least two Italian visas during this time. Leonardo Bencini noted that in 2014 the number of visas received by citizens of the Russian Federation increased by $130 \%$.

Samara region has a foreign policy achievements with Italy. 25 September 2008 Palermo has become a city partner Samara. In Samara works Honorary Consulate of Italy in Samara region and the Republic of Tatarstan.

\subsection{Interesting resources}

Convenient geographical location of the central part of Russia created the possibility for the development of a large (one of the most significant in Russia) transport interchange hub. Region area of 53,6 thousand $\mathrm{km}^{2}$ and is located in the South-East of the European territory of Russia on the both parts of the course of Volga river in $1098 \mathrm{~km}$ from Moscow. In addition to a wide variety of tourist facilities in Samara there are tourist resources of interest to Italians. In the XIX century came to Samara circus troupe of Ceneselli, Ferroni, Truzzi and Quirini, magician Martini. In Samara the Church, Lutheran Church and a chapel connected with the Roman Catholic faith. In the Behm's shop in the XIX century was sold to Italian musical instruments. Lived and worked in Samara Alexey Tolstoy based on "Pinocchio" wrote the tale "The adventures of Pinocchio", and statue of Pinocchio . In Samara at different times, the authorities often bought Italian cars FIAT. In Samara in the second world war often came Palmiro Togliatti, in whose honour after the war called the second largest in the Samara region of the city (Aleksushin, Tours, 2014). In the second largest city of Samara region, Toglyatti, you can visit Technical Museum them. This Museum was established in AvtoVAZ, which helped build the Italians, and the first car which was a FIAT-124. K.G. Sakharov JSC «AvtoVAZ» in Togliatti demonstrates to guests military equipment of the 1st and 2nd world wars, modern weapons. The museum has a real submarine length of $90 \mathrm{~m}$ and an armored train, running kart. In a separate pavilion viewers can take pictures in VAZ, did not follow the series.

Samara region has all the necessary resources for the active development of almost all kinds of leisure tourism and recreation. Participating, ski and cruise tourism developing successfully, road trips tourist routes becoming more and more popular. Only in Samara can be seen standing upright space rocket "Soyuz" with the Museum "Space Samara", 37 metre deep Earth bunker of Stalin, the biggest Kuibyshev square in Europe and 2nd in the world by area, one of the 10 highest monuments (of Glory, 52 meters) in the world, with a length of 8 kilometres of the embankment of the Volga river, formed by a sharp bend of the Volga Samarskaya Luka. Zhiguli mountains preserved ancient originality of the animal and of vegetable world, it was told to the present day features a prehistoric appearance of the Earth. Created by long work of water, sun, wind and surf, about 3 million years ago Zhigulevsky peninsula go into Akchagyl sea. In the region - more than 200 monuments of nature, including the national parks "Samarskaya Luka" and "Buzuluksky Bor", FSBO "Zhigulevsky State Natural Biosphere Reserve of them. I.I. Sprygin" and many unique caves and sources. Several places of the Samara region will be of interest to fans of the UFO. Music festivals: International «Rock over the Volga», ethnic music «Drums of the world» and accordion music «Vivat, Bayan», Russian bard song to them Valery Grushin, electronic music and extreme sports «GES-fest», of music festivals «Meta-fest» and others enter the Samara region in the top 5 of Russia in event tourism. Young military-historical nature festivals growing rapidly: the historical martial arts for the Cup $\mathrm{CHM}$ «Ancient World», «Military work» (on the site of the Battle of the Kondurcha river 1391) and others. The abundance of transport facilities in the region has led to the emergence and development of technical festivals: «Car-fest», «Autograd" military-sports show in Bobrovka and others. The multinational composition of the Samara region formed an interest in ethnic festivals, «Syzran tomato», the festival of cherry pie, «Anatologiya» and others. The region has more than 30 health hotels, 125 recreation centers (most of which are located on the river banks), more than 250 hotels. FSBO health hotel «Volzhsky Utes» has frequently been the site of important international meetings, but is available for all guests. FBMO health hotel «Sergievskie Mineralnye Vody», which has existed since 1768, has unique resources. Almost half a century people, which had undergone heart attack and stroke, are going to follow-up care at JSC health hotel them. 
Chkalov. «Water «Studenaya» from the wells of the Samara branch of FSUO health hotel «Mozhayskiy» on therapeutic effects on the digestive system than many counterparts. Samara region won the right to host the FIFA World Cup in 2018, but this creates a unique opportunity and increased responsibility. In Samara the number of Italian tourists interested in a tour of "Space Samara", as manufactured in Samara space rocket "Soyuz".

Italy octupole the number of Russian tourists in 2010, while Finland and Germany, in 2011 - and even Spain and Greece. Italy is one of the leading countries ranked 5th place in terms of inbound tourist flow and 4th place income from tourism. Incoming and outgoing tourism Italy has a distinct seasonality, due to the climatic conditions of the country. Seasonality in the travel of Italians abroad depends on the direction of travel.

Italy is reasonably one of the most attractive for Russian citizens from a tourist point of view the country. In Italy there are more than $50 \%$ of the world's cultural heritage, much more than any other country in the world. In Italy is a lot of unique objects, unique in the world.

In Italy there are all favorable factors: natural, cultural, social, economic, which contribute to the development of tourism. The greatest role is played by cultural and natural background. Some factors exist only in Italy, increasing its tourist appeal.

There are many natural sites for tourism. In mainland Italy is separated from the rest of the continent highest mountain in Europe by the Alps system. Only in Italy there are about 70 large caves and several hundred caves. Some caves due to the constant humidity, the presence of mineral springs, steam, mud have medicinal value. Coastal areas of Italy, especially the Ligurian Riviera, Ionian sea, Sicily and Sardinia are particularly mild climate. Here the difference between the average temperatures of the coldest month (January) and hottest (July) is about $15^{\circ}$. Therefore, on the coasts of Italy, especially on the Ligurian Riviera, chain stretch is known climatic health resorts. Thermal resorts are an integral part of water resources.

Italy has played an important role in shaping the history and culture of the countries of Western Europe. Two thousand years ago this country was the centre of the Roman Empire. In Italy the tourist from Russia is most like the ancient Roman and Italian cities (Rome, Florence), water cities Venice and Genoa (the capitals of the medieval Maritime trade unions), the beaches of Sicily, luxury hotels, ski resorts. Huge interest in Italy makes culture lovers as immortal works of Michelangelo, Giotto, Cellini, Dante, Boccaccio, Leonardo da Vinci, Botticelli, Raphael, Caravaggio, Rubens, Vivaldi, Pergolesi, Cimarosa, Boccherini, Rossini, Bellini, Donizetti, Verdi, Pavarotti. The invaluable contribution of Italy to the development of world musical culture. In the XI century Italian monk Guido d Arezzo has created a musical letter gave the name to the seven notes of harmony. Continuing the ideas of Copernicus, Giordano Bruno for his presentation was burned at the stake by the Inquisition in Rome. Galileo Galilei laid the foundations of mechanics. The emergence of Roman museums and their high artistic level was determined by a passion for collecting noble families and the patronage of the popes, contributing to the creation of the Vatican museums and public Capitoline museums. The most famous national gallery of ancient art, the Borghese Gallery, the national Roman Museum, etc. Of particular interest to visitors Italy is an opportunity to visit the Vatican.

Traditional Italian cuisine is widespread and popular all over the world, thanks to dishes like pizza and pasta. It is very diverse and regional, each region has its own traditional dishes.

The sport traditionally occupies in the life of Italians. Italy was one of the originators of the Olympic movement.

The state manages the tourism and tourism activity requires intervention from the state. In 1997 Italy joined the Schengen agreement and the visa section of the Embassy began issuing "Schengen visa". A Schengen visa issued by one of the countries participating in the agreement, valid in all participating countries. All foreigners legally residing in the territory of one of the Schengen countries, are eligible for short-term visa-free visits to any other state areas, provided that they are traveling with a passport recognized by all the member countries of the agreement, and the permit issued by the authorities of the country of residence. Approximate annual income from tourism reached 10 billion U.S. dollars. Share in GDP of $12 \%$.

In the organization of tourism in Italy for the residents of the Samara region has problems, chief among them - a rarity study and use of the Italian language. On the official websites of tourism in Italy no Russian language.

Italy is the cradle of many fashion designers and international designers. Many well-known brands of goods is said to have originated here. What you sometimes find in Russian stores under the brand "Made in Italy", in most cases is a counterfeit, or low-quality samples, not justifying well-known brand. Therefore, if you have the money and can afford known fashion items, Italy provides you with a wide selection of products, both expensive and reasonable to average income.

For Italian tourists would be interested a mini-trip around the world, which could be called Around the world through Samara. In Samara could participate in river Zhiguli circumnavigation around Samarskaya Luka, confirmed the idea of the whole tourist route. Given the high level of service the new terminal of the international airport "Kurumoch", and the 
railway station in Samara, which is considered one of the highest in Europe, and the availability of firms involved in the organization of specialized railway tours, this idea would become the hallmark of the Samara-Italian tourism.

River transport in Italy is underdeveloped due to the lack of large rivers. In this regard, the Italian tour will be very interesting to the diverse tourist routes, the Volga with its tributaries of the Kama and the Oka. Numerous tourist fleet of Volga will give Italian travelers the experience that they cannot receive at home.

In Samara and Samara region development strategy, including the tourism industry. However, minor attention is given to Italy. In these strategies it is possible to make changes, but this requires political efforts of the Italiian side. In this case, the administrative resource will provide additional opportunities for development.

In particular, the joint interaction of Italy and Samara region would be the creation of interesting for tourists the Museum samaro-Italian automotive history, which colleagues from Italy helped to create. Such a Museum could become not only an interesting place for tourists, but also to help strengthen samaro-Italian business tourism.

Italian students would like to participate in our student project forum IVolga, each year passing near Samara in the 3rd week of June.

Requires cooperation at the level of exchange of commands between the military-historical festivals of Italy and Samara region.

Given the active development of sports in recent times in the Samara region, would be beneficial exchanges of sportsmen between Italy and the Samara region for their participation in different sports.

\section{Discussion}

Thus, Samara and Italy interested in each other.

Russian tourists buy vouchers for a greater number of days among the three spend abroad and always use additional services.

How wishes to turn into a practical result?

Soon Rosturizm will open three offices in Germany, China and Italy to promote Russia in these countries.

In Samara now is a lot of discussion about the date of creation of the historic settlements on the site of our city, caused by the details of maps of the Italians Pizzigoni and fra Mauro, Samar which was on the Volga river near the modern Samara for a century or two before the current term.

\section{Results}

Russia and Italy - the interesting state in the world. Impact advantages of Russia in recreation-geographic location (proximity to European and East Asian tourist markets) and best security historical and cultural recreational resources.

Need public samaro-italian tourist organization to increase the motivation of tourists both in Italy and in the Samara region, to visit our regions. This organization could take over the organization of education, exchange of delegations, language schools, and economic interaction.

\section{References}

Statistic of Rosstat (2003). http://www.gks.ru/bgd/regl//b04_42/lssWWW.exe/Stg/d010/i010040r.htm. Aleksushin, G. V. (2014). Tours in Samara for foreign groups (Samara tour route). - Samara: Prime.

Bondarovich, A. A. (2003). Recreational resources of Europe and their evaluation. - Sunct-Peterburg. SPb: Nevils.

Tonini J. (2013). The tourist exchange between Italy and Russia. Вестник PMAT. (3). http://cyberleninka.ru/article/n/obmen-turistamimezhdu-italieyi-rossiey 


\section{Appendix}

Table 1. The development of tourism in Russia, millions people, out/in (place in the world) (Statisic, 2003, Tonini J., 2013, The tourist exchange).

\begin{tabular}{ccc}
\hline Years & Tourism in Russia & 1 tourists on 1000 citizen in Russia \\
\hline 2004 & $6.6 /$ & $?$ \\
2005 & $6.78 /$ & $?$ \\
2006 & $7.75 /$ & $?$ \\
2007 & $?$ & 2,15 \\
2008 & 111.3 & 3,09 \\
2009 & 19.5 & 3,25 \\
2010 & 112.6 & 4,58 \\
2011 & $114.5(13)$ & 5,59 \\
2012 & 115.3 & $?$ \\
2013 & 118.3 & $?$ \\
2014 & 112.0 & $?$ \\
\hline
\end{tabular}

Table 2. The development of tourism from Russia to Italy and from Italy to Russia, people (places), (Tonini J., 2013, The tourist exchange).

\begin{tabular}{cccc}
\hline Years & Russia to Italy & Italian to Russia & Russialltalian \\
\hline 2007 & $305000(?)$ & $182000(?)$ & 1,68 \\
2008 & $438000(?)$ & $191000(?)$ & 2,29 \\
2009 & $461000(?)$ & $198000(?)$ & 2,33 \\
2010 & $649000(6)$ & $216000(?)$ & 3,00 \\
2011 & $793000(9)$ & $125062(6)-$ & \\
2012 & $571000(8)$ & $246000(?)$ & $-3,22$ \\
2013 & $?$ & $118729(6)$ & 4,84 \\
2014 & $?$ & $117927(6)$ & $?$ \\
\hline
\end{tabular}

